\title{
Kala pani revisited Indian labour migrants and the sea crossing
}

\author{
Crispin Bates and Marina Carter \\ Crispin Bates is professor of South Asian history, University of \\ Edinburgh
}

Marina Carter is honourary fellow, School of History, Classics and Archaeology, University of Edinburgh

\begin{abstract}
This article examines the reconstruction and deconstruction of the concept of काला पानी or kālā pānī, meaning the 'black waters', which all Indians must cross when migrating overseas. From its origin as a Brahmanic text warning about the dangers of oceanic voyages, through its dissemination as a more generalised stricture against emigration and its use and abuse as a British colonial construction, to its recasting as a historical trope and a literary device, the everchanging influence and meaning of kala pani is interrogated and assessed. Contextualising the kala pani trope against the setting of sepoy, convict and indentureship voyages, this study also evaluates its historical validity and importance in colonial and nationalist realities. Finally, the symbolic value of the kala pani and its reworking as a literary device are explored.
\end{abstract}

\section{KEYWORDS}

kala pani and migration, sepoys, transportees, labour migration India, caste and kala pani, nationalism and migration India, kala pani as metaphor 


\section{DEFINING KALA PANI: HINDU TEXTS AND THEIR INTERPRETATION}

In Hindi or Bhojpuri (the language of the large number of Bihari North Indian overseas migrants), kā $\bar{a}$ means black and $p \bar{a} n \bar{\imath}$ means water. The term kala pani can be written either as two separate words or as a single concept: kalapani. This 'black waters' trope is said to derive from long-held notions that sea crossings were antithetical to Hindu culture, entailing a separation of the traveller from the holy Ganges, thereby breaking the reincarnation cycle and engendering a loss of caste (for a summary of this debate Mehta 2004a). Ancient Indian texts have been studied to investigate the wording and applications of this sanction. This research and the conclusions that can objectively be drawn with regard to the importance and extent of the kala pani stricture are briefly summarised below.

Scholars of ancient India have noted that a ban on sea travel is mentioned in the fifth-century BC sutra of Baudhayana, while the texts Manu (III. 158, 16-17) and Ausanasasmrti (V. 525-6) record that a brahman who had undertaken a sea voyage was considered a sinner, without, however, specifying that the individual would lose caste and/or become socially unfit. Indologists have speculated that lower castes may have considered that the taboo applied to them merely as a way of emulating Brahminical practices (Bindra 2002). It has further been contended that the textual concerns with religious purity did not actually serve to prevent sea travel. As Basham concludes, Indians of all castes, including brahmans, frequently travelled by sea. Hence, 'the texts which forbade or discouraged ocean voyages cannot have been followed by more than a small section of the population' (Basham 1964: 162-3). Michael Pearson comments that the 
Sastra prohibitions 'are to be seen as precepts rather than strict rules. This is demonstrated by the way Hindus have crossed the ocean since time immemorial, even if the sea does not play a major role in Hindu thought.' Pearson notes, however, that 'lower caste people especially were relegated to occupations which higher castes found polluting, so that coastal trade and fishing was typically, then and now, done by folk very low in the hierarchy' (2007: 47). Bengali historian Tapan Raychaudhuri offers an interesting theory as to the rationale behind the development of the kala pani strictures, contending that they probably had 'historical origins' involving 'the destruction of Indian merchant fleets by Arab pirates' (1988: 37).

In the nineteenth century, there are several recorded cases of prominent individuals facing punitive consequences following sea travel: Swami Vivekananda, returning from the 1893 Chicago gathering of world religions was barred access to a temple, and Mohandas Karamchand Gandhi was required to undergo an 'expiatory ritual' when he returned to India from South Africa in 1915. Most famously, the early nineteenth-century merchant, banker, industrialist and philanthropist Dwarkanath Tagore (grandfather of Rabindranath Tagore) 'faced excommunication by the inner circle of his family' following his return from his first trip to Europe in 1842 (Mortuza 2017: 284; Mandal 2014). However, there were striking discrepancies in the upholding of kala pani strictures, and it has been argued that

the nineteenth century practice of ostracizing those who had gone abroad, less strong in Maharashtra than in Bengal, owed much to the arrogance of those ostracized. If the 'England-returned' were a little more respectful to their own society, as was the case in Maharashtra, very probably the problem would disappear. (Raychaudhuri 1988)

In the case of Dwarkanath Tagore, his own domestic difficulties did not prevent him three years later from returning again to Britain (where he eventually died in 1851). 


\section{PRACTICAL APPLICATIONS OF THE KALA PANI TROPE: SEPOYS AND TRANSPORTEES, I 795-I830}

The ancient strictures surface in the colonial archive in surprising and revealing forms. Concerns about caste reveal as much about stereotypical and idealised British attitudes towards their Indian subjects as they hint at manipulation of the same for subaltern mediations. Sepoys and convicts used self-definitions of caste, status, privilege and taboo to engage in a dynamic process of negotiation with their employers and rulers. Evolving notions of kala pani thereby serve as a revealing study of this fluid arena of identity recognition and contestation.

British colonial wars in the late eighteenth and early nineteenth centuries offered a fertile ground for the testing of the kala pani trope. In late 1795, when the 15th Native Infantry were requested to embark for Malacca, concerns centred on assurances that families would be supported in the absence of their menfolk and that suitable provisions would be stocked for their use on board ship. After some consideration, the sepoys agreed to embark, but subsequently withdrew their consent, citing concerns about the sea voyage. This refusal was viewed by the commanding officer as a desertion of duty, leading to a mutiny and a violent confrontation with the battalion in question, which was subsequently broken up. Anxious to prevent further disaffection, it was henceforth decided to take care to limit overseas expeditions to volunteers who would be handsomely remunerated (Banerjee 1969). Subsequent expeditions, for example to the Mascarene islands in 1810 , were raised through the creation of volunteer battalions; the rolls indicate that large numbers of Hindus embarked, and although caste is not specifically designated in the military registers, the names listed would appear to indicate that 'high caste' sepoys were included. ${ }^{1}$

Disaffection among sepoys ordered to proceed to Rangoon in 1824-5 initially revived concerns about the kala pani. A group of those questioned mentioned that the Subadar Major had warned them that they would need to board a ship to Rangoon and that 'he would there and then make them eat from the same dish'. However, 
if they were provided with 'carriage cattle, double batta and if the Subadar-Major and the Havildar were put to death, they would march'. ${ }^{2}$ A later enquiry discovered more logical reasons for their disaffection: the Bengal Native Infantry (BNI) sepoys recruited principally from Bihar, Benares and Oudh were aware that the 'climate' of Burma was 'extremely hostile to the constitution of strangers and to have proved lamentably fatal to multitudes of their brethren'. Furthermore, the journey entailed a long separation from home, and rendered them unable to take part in religious rituals which they would normally have been granted leave of absence to attend. Finally, it transpired that the Subadar Major was a Muslim, and had secured the promotion of one of his relatives to the post of Havildar, over other more senior men. He was, furthermore, 'extremely vituperative and abusive' and consequently so unpopular with the sepoys that attempts had been made to burn his hut and that those believed to have been involved had been ejected from service (Sen 1961).

A close reading of the sources shows therefore that sepoys had multiple reasons to be averse to service in Burma and expected to be remunerated accordingly. Epidemiological reasons for fear of longdistance travel were well founded. A mid-nineteenth-century medical report on shipboard mortality of sepoys and indentured labourers underscored the dangers of travel to regions with endemic disease to which the soldiers and workers had no acquired immunity:

To so great an extent are natives of Behar, Oude and Upper India generally affected by a residence in the alluvial plains of Lower Bengal, that Sepoys, a strong, healthy, well-fed class, pine away and die in such numbers, as to have led to the relief of regiments of the line every two, instead of every three years. The corps sent to Burmah are decimated; and those serving in the Eastern Districts of Bengal are equally unhealthy. (Mouat [I 857])

The extent to which colonial orientalist perceptions were predisposed to accept cultural rather than medical explanations for the supposed 'dread' of sea travel is a moot point. British officials certainly had a distinct preference for superstitious rather than 
rational explanations for the behaviour of their subjects. ${ }^{3}$ Within Britain itself, banishment of convicts overseas in an era before the advent of global communications involved a 'wrenching loss of personal identity' and was considered 'a form of death' (Yang 2021; also Meredith 1988). It is no surprise therefore that transportation overseas and the kala pani concept was exploited in the creation of disciplinary measures in India. As Clare Anderson explains, British policy appeared to be influenced by the "perception that transportation was a particularly appropriate punishment for India's "caste-based" society'. It was thus contended that the 'innumerable evils of caste defilement associated in the minds of Indians with the crossing of the kala pani were more efficacious as a deterrent to crime than even the death sentence' (2000: 16).

At the same time, there can be little doubt that the British viewed transportation as a convenient means of supplying forced labour to disparate territories that would otherwise have found difficulty in procuring and remunerating much needed workers. As Anand Yang has argued,

the transportation of convicts in the early nineteenth century was as much about mobilizing their bodies for building the infrastructure of the rising British Empire in the region as it was about punishing offenders by removing them from their homes and compelling them to cross the kala pani, or black waters. (Yang 2003)

In this respect, both the British administrators and the Indian sepoys had good reasons to inflate the importance of the kala pani trope and thereby serve their own interests. It is thus clear that, in applying the concept of the fear of the 'black waters' to criminal transportees, a colonial construction existing primarily in the British imaginary of the Indian mindset was rendered and reinforced as a dogma rooted in indigenous culture and history.

The ambivalence of the kala pani construct is further demonstrated by the admitted concern of British administrators that some individuals deliberately committed crimes in order to be transported 
as a means of joining relatives already condemned to be sent overseas: 'This of course challenged the colonial construction of transportation as a punishment worse than death, with the crossing transgressing caste boundaries and thus causing social death' (Anderson 2005). Furthermore, the fears associated with ocean crossings may well have had as much to do with the novelty of the experience and the very real dangers of long sea voyages in the age of sail as with the perceived loss of status. Anderson explains 'Many Indians had never before seen, let alone been to sea, rendering the ship an important tool of convicts' cultural and geographical displacement [and] the journey itself an important element of the punishment' (2013). Finally, the kala pani construct was considered to be of import only to those who considered themselves to be 'high caste' and even they could find means to circumvent perceived sanctions: 'it is important to appreciate that although in India some convicts were outcaste by the voyage over the kala pani, this was not always the case (or they could perform particular ceremonies to wipe out the effects of it), and so there was never universal antipathy to it' (Anderson 2016: 23-4). There was, furthermore, no conceivable religious reason why Muslim convicts should be appalled by the idea of travel overseas, as was highlighted by David Macfarlane, in a dissenting minute to the 1838 Report on PrisonDiscipline in India (Committee on Prison-Discipline 1838).

\section{THE KALA PANI TROPE AND THE INDENTURE DIASPORA, I 834-74}

From the 1830s until the early twentieth century, the vast majority of the millions of long-distance voyages made by Indians were not by convicted transportees or reluctant sepoys - they were sea journeys taken by contract labourers. In the archives that document these migrant flows, it is striking, once again, to note the extent to which the kala pani concept appears overwhelmingly from the mouths and pens of British investigators and administrators rather than the plaints or petitions of migrants themselves. Furthermore, it is 
instructive to ascertain the degree to which kala pani may be read in relation to important political milestones, particularly the Revolt of 1857. Reading against the grain of the colonial archive underscores how significant the non-verbalised conveniences of kala pani were; the notion of transportation as a peculiarly cruel and appropriate punishment for rebels and mutineers was an expedient cloak for the dual ambition of ridding India of miscreants whilst assisting the labour requirements of export producers elsewhere in the Empire.

The extraordinary generalisations of the otherwise respected British surgeon Frederic J. Mouat, who spent much of his life in India and made a journey with Indian labour migrants in 1851, serve as a revealing backdrop to the practical applications of the kala pani trope in the context of the nineteenth-century indenture diaspora. His characterisations of the 'sickly' Bengali with his dread of the kala pani, and the more seaworthy, fearless Tamil, were countered by emigration officials but are indicative of the propensity for British colonial officials to give credence to the importance of personality traits over epidemiological explanations, which were of course still poorly understood at this time (Mouat [1857]; Boodhoo 2010).

The wholesale slaughter of mutineer troops post-1857 was neither a sustainable policy nor one that senior officials had the stomach for, once the fervour to 'avenge Cawnpore' had subsided. It was also a lamentable waste of India's greatest resource, manpower, which was badly needed elsewhere. The notion that transportation was an even worse punishment than execution was a convenient means to dispose of the mutineers relatively humanely whilst providing much-needed assistance to the labour-starved sugar colonies in the wake of slave abolition and its drastic effect economic collapse. General Sir Charles Napier was thereby able to proclaim proudly 'I did not hang the men of the 32nd Native Infantry because I thought transportation for life was the most feared punishment of the two' (Samaroo 2004). It is tempting to conclude that British officials were less concerned with the use of kala pani as a punishment than with its convenient solution to two 
imperial problems: diverting the recalcitrant and famished of the former sepoy recruiting districts away from India and supplying the burgeoning demand for plantation labour.

From the sepoy's perspective, emigration was surely a preferred alternative to death, starvation or transportation. In the words of Hugh Tinker, 'the Mutiny ... created turmoil throughout northern India, from Delhi to Patna. Many were uprooted, losing land and livelihood, and were glad to accept the chance of a new life beyond the seas' (1974: 97-8). Both sides were anxious to disguise this policy of emigration over punishment. As Samaroo contends, it was logical for many former sepoys keen to escape 'brutal punishment at home or, alternatively, banishment to the hellish life in the Andamans' to seek 'refuge in indentureship. However, they did their best to conceal their sepoy identities and to put up with indignities in order to maintain their concealment' (2004: 85).

Geoghegan's (1874) report on colonial emigration stressed that the bulk of immediate post-mutiny emigrants went to Mauritius. Noting that some 90,000 emigrants left India in 1858 and 1859, he coyly admitted 'I believe the sugar plantations were prosperous at the period, but it was shrewdly suspected that the mutiny had much to say to it, and that many of the emigrants crossed the kala pani to Mauritius to avoid a compulsory sea trip to Port Blair'. While many British Indian officials, like Geoghegan, viewed migration as a means of solving India's overpopulation and immiseration, others sided with local landowners and businessmen who were concerned about the transfer of bonded and cheap sources of labour to colonial enterprises. Cases of Indian magistrates frightening off would-be emigrants with lurid accounts of the 'kala pani curse' were not uncommon, as a report of the French Governor of Pondicherry, dated 25 September 1865, indicates (cited Singaravelou 1975: 38). Nevertheless, as migrants began to return from the sugar colonies or to contact absent relatives via letters and money orders, kala pani fears must have been undermined. Indeed, the expansion in the social classes migrating post-mutiny itself helped to act as a counterpoint to the 
scare-mongering of opponents of indenture. In 1862, the Protector of Emigrants in Calcutta, Captain C. Eales, asserted:

Emigration, as now conducted, is by no means confined to the agricultural population, as during the past two years a widespread impetus has been imparted to other classes, who have been taught to look to Emigration as a relief from the disturbing effects of the Mutiny, the disbandment of the Native Army, and, lastly, from the sufferings occasioned by the recent famine.

Eales remarked that the addition of a 'proportion of persons of superior intelligence and independence of thought and feeling' aboard each emigrant ship was bound to impact upon the mass, who would be unlikely to remain 'blindly submissive'. Added to what the Protector of Emigrants described as a 'high rate of remuneration' obtainable for their labour in the colonies, he explained that the prospect of personal enrichment had rendered migration desirable to 'several classes'. That this was no pipe-dream was demonstrated by returnees who had amassed on average between 3,000 and 6,000 rupees over a decade or so abroad. Eales therefore dismissed the notion that emigration was a dreaded last resort of the desperate, even going so far as to state that many looked forward to their day of departure, and contending that fear of the kala pani was by no means as universal as some believed:

if further evidence is necessary to shew that, religious scruples or caste prejudices do not deter them from making a sea voyage, it is to be found in the fact of their willingness to re-embark in instances when ships have had to put back from sea from stress of weather or otherwise.

Reflecting on the dramatic increase in the numbers of Indians undertaking sea voyages in the nineteenth century, Daniel Bass has commented that this did not take place because of a change in attitudes to sea travel per se, rather, he points out, "many Indian migrants would have been more than happy to lose their caste position, since caste was one of the many factors supporting their low-status and poverty in India' (2017: 27). 
While escaping sepoys and those who had suffered caste discrimination may well have contributed to a wider social acceptance of overseas sea travel, opposing forces were at work. The political ramifications of key events such as the 1857 uprising undoubtedly played a part in shaping perceptions and expectations. Clare Anderson (2009) draws attention to the ways in which the transportation of rebel leaders to the Andaman islands briefly invested the term 'kala pani' with new meanings associated with convict punishment. Furthermore, the educated leaders of the revolt were instrumental in helping to shape organised resistance to British rule, and nationalist opposition to the international subjugation of the 'coolie' brought about further refinements to the kala pani trope into the twentieth century.

\section{NATIONALISM AND EMIGRATION: REVITALISING THE KALA PANI TROPE I880-I920}

Historical accounts of indenture refer frequently to the reports of George Grierson and Major Pitcher. Both men were deputed to visit areas of recruitment of indentured workers in northern India and to investigate the workings of the system. Their records of interviews with migrants, returnees and employees of the emigration agencies provide an unusually detailed series of interactions with subaltern men and women pre- and post-indenture and offer a snapshot of the rumour and reality surrounding overseas travel in the 1880 s. Grierson stressed, while visiting a depot in Bankipur, that 'in explaining to the coolies where they are going, the word "tapu" [island] is always used, and never "kala pani" the use of which would be quite sufficient to prevent many from enlisting' (1883: 4-5). According to Hugh Tinker, the overseas sugar islands 'were generally known as Tapu' and while 'anyone who disappeared from the village (absconded, lost, or murdered) was said to have gone to Tapu' (1974: 120), presumably with increasing numbers of returnees, the 
term 'tapu' lost some of the negative connotations which were associated with kala pani. Grierson pointed out that 'another example of the way in which emigration gradually overcomes the prejudices which formerly existed [is] the new caste rule which is gaining ground, to the effect that a man can eat anything on board ship, a vessel being like the Temple of Jagannath, without caste restrictions'.

Major D. G. Pitcher, a judge in Lucknow who was, like Grierson, commissioned to write a report on the operations of indentured emigration, remarked that recruiters everywhere complained 'of the way in which they are insulted at times in the bazars, and of the language and falsehoods with which their recruits are assailed'. In some villages, creditors and zamindars were known to obstruct the departure of indebted labourers, while Pitcher noted that 'educated native gentlemen' were very sceptical about the motives of the British in authorising emigration in the interests of populating distant 'desert lands'. He deprecated the use of the term kala pani by magistrates, which alarmed recruits, who associated it with transportation, i.e. with punishment rather than with opportunity to earn good wages. Conversely, he pointed out that migrants returning with savings acted as a great incentive for recruitment. ${ }^{4}$ George Grierson also commented on the attempts of zamindars to influence antiemigration views: 'It is they who are able to make themselves heard, and who have most means of forming the ideas of the people under them. To a zamindar every coolie who emigrates is looked on as so much property lost.' In Shahabad, a landlord sought to convince him that high-caste Indians were averse to emigration, yet Grierson contended that the registers told a different story - high castes were migrating in large numbers from this overpopulated district despite recruiters' fears of going into villages where they would face obstruction from 'zamindari servants'. Grierson asserted that Indian police constables were generally also 'actively opposed to emigration', in his view because 'they look upon the colonies much as they look upon indigo planters - as private speculators who wish to exploit India'. They considered the recruiter to be 'a private speculator,... 
an obnoxious foreigner, or at least the servant of a foreigner'. The dissemination of anti-emigration rhetoric led to attacks on recruiters and abuse heaped on migrants themselves 'for leaving their fatherland' (1883: 16-18).

It is likely that assaults on recruiters and assaults on migrants in village and bazaar alike, as described by Grierson and Pitcher, did not only mark the well-known tactics of the landed classes and their servants to dissuade exploited labour from seeking better opportunities outside India. They also point to the growing disaffection with British rule and with the treatment meted out by white employers to 'natives' and 'coolies' which would soon be articulated with the formation of the Indian National Congress in 1885.

Ashutosh Kumar has underscored how the nationalist campaigns against indenture of the late nineteenth and early twentieth centuries, in which the Hindu revivalist organisation the Arya Samaj played a prominent role, permeated popular culture through the composition of folk songs. Amongst other things these lamented the trickery used to force migrants to cross the 'kala pani' (Kumar 2015: 47). Over succeeding decades the kala pani trope would become a powerful weapon in the hands of nationalists who viewed indenture as a symbol of the international subjugation of the Indian and a source of national shame. This was forcefully articulated by Lucknow poet Shikohabadi (1819-81) when he wrote: 'The prisoners' evil fate made the water black [kala pani] . . . In the darkness of the evening of exile, they were granted the kohl of Solomon' (Anderson 2016). The voices of migrants are rarely accorded a place in the colonial archive but where they appear it is frequently to contest the descriptions of their life experiences offered by critics, evincing pride in their courageous journeys and scorn for the fearful villagers who remain at home trapped in ignorance. George Grierson described meeting a woman returnee who had a contract with a local recruiter, Dip Lal, to feed migrants in North Bihar en route to the Calcutta depot. She told him that she had spent 12 years in Mauritius before 
returning to Bihar where she 'settled down in a comfortable shop, a sort of railway refreshment room for natives'. She scorned her compatriots who were fearful of migration as 'cowards'. Even more telling is Major Pitcher's record of a noon meeting with Ganga Din Misr of Adampur, a return emigrant from Demerara who 'came to see me and tell his story,... [and] gave a curious account of his voyage: how he went not only over the kala pani, but also a sufait, lal, nila, and hara pani'. Surely Misr, in visiting Pitcher to recount his adventures, was wanting to articulate - in describing the waters as not only black, but also white, red, blue and green - that the realities of going overseas (as explained to recruits headed for British Guiana) were far more complex than the simplistic arguments propounded by proponents and detractors of the indenture system alike. ${ }^{5}$ Of course, the prosaic language of the subaltern was no match for the skilled wordsmithery of the Urdu poet or the haunting lyrics of a Bhojpuri folk singer.

In response to the representations of Gopal Krishna Gokhale in the Imperial Legislative Council in 1910, the Viceroy promised to end overseas indentured migration in due course. In 1916, a final resolution proposed by Madan Mohan Malaviya was passed, committing the government to this course of action. The coup de grâce to overseas indentured migration was ultimately delivered by a shortage of shipping in World War I. Thereafter, the association between overseas labour migration and the kala pani began to fade. Alongside this decline in indentured labour migration overseas, there was a growing migration of clerks, merchants, engineers, schoolteachers and the like to South Africa, Burma, Malaya and East Africa, as well as of students to Japan and North America for training, and to England, primarily to study law. Amongst the upwardly mobile Bengali Kayasth community, this presented a dilemma when they were faced with the criticisms of conservatives who wished to exclude England-returned gentlemen from the annual Kayastha conference (Carroll 1979). Kayasthas were a clerical caste in Mughal Bengal, who readily 
found employment under the British. As with the Bumihar (cultivating) Brahmins of north India who served in the Bengal army, Kayastha prosperity was intimately linked to Government service, and fuelled claims to higher religious status exemplified through newly invented rituals and rules of cleanliness and purity. Formerly a north Indian Kayasth's local biraderi (brotherhood) would welcome home migrants with only the expectation that he throw a feast, make a charitable contribution or (more rarely) take part in an expiatory ceremony (prayashcitta). Now the issue was becoming controversial amidst claims that were being made to higher caste status. A few months before his return to India from studying manufacturing in Japan and at the Agricultural College at Corvallis, Oregon, in North America (both adventures accompanied by a wonderous array of mishaps and revelations), the north Indian Kayasth student Mahesh Charan Sinha, sometime manager of the Kayastha Samachar, and former joint-secretary of the Kayastha Institute of Lucknow, authored a strongly worded article on 'Caste and Foreign Travel' which appeared in the Hindustan Review in March 1907:

[T] he extent of degradation, which India has reached, how deeply has superstition permeated every inch of Indian ground cannot be realized unless one goes out of India and inspects things personally, and compares the people of India with those of other counties. It is then alone possible to find out how narrow-minded and extremely short-sighted are the views and practices even of those that pass for educated in India.

These men utterly unconscious of their ignorance and superstition attach the highest importance to foolish frivolities. With them what to eat, where to eat, at whose hands to eat, is all important - foolish considerations for which the rest of the globe has not a moment's thought to bestow. Oh! what a pity that the intelligent Hindus who can unravel the most complex mysteries of Metaphysics should be so perverted as not to be able to understand the simplest of propositions that if the breaking of caste and removal of such absurdities as forbidden land and forbidden food has not injured the whole 
world, how can it injure Hindus alone who form but a fractional part of the whole world. (Carroll 1979: 295)

Ultimately, liberal views within the Kayastha Conference in favour of long-distance sea voyages prevailed and Mahesh Charan Sinha and others were welcomed home with open arms.

At the same time as north Indian Kayastahas were debating the hazards of pollution and travel overseas, 'kala pani' was acquiring an increasingly political meaning within India, one entirely different from its original significance as a religious injunction occasionally encountered among upper-caste Hindus. Between 1905 and 1908, just as in 1857, transportation overseas became once again the preferred punishment for political offenders during the 'Swadeshi' movement in Bengal and in suppressing the strikes organised by Arya Samajists in the canal colonies in the Punjab. Ghadrites and other so-called terrorists were next to be shipped to the cellular jail in the Andaman Islands in their hundreds during World War I, according to the terms of the Defence of India Act of 1915. The most famous of the freedom fighters incarcerated at this time was Vinayak Damodar ('Veer') Sarvarkar, the Hindu nationalist and author of banned book The Indian War of Independence, 1857 (1909) and Hindutva: Who Is a Hindu? (originally, Essentials of Hinduism) published in 1923. Savarkar was imprisoned in the cellular jail in 1911 for abetment in the murder of the Collector of Nashik and conspiracy against the imperial government arising from his involvement with a revolutionary organisation called Abhinav Bharat ('Young India') and with activists at India House, a student residence at Highgate in London. In 1927, he wrote of his experiences of confinement in the Andamans in the book Majhi Janmathep (My Life-Term). Originally written in Marathi, it was translated into Hindi with the simple title Kala Pani. This shows how in the twentieth century 'kala pani' became a simple metonym for transportation to the Andaman Islands, and indeed the name for the cellular jail itself (that was completed in 1906). 
Transportation to kala pani thus became recognised as a symbol of colonial oppression, and badge of pride for Indian nationalists. Educated political transportees returned from the Andamans and authored powerful indictments of their 'kala pani' exile. The infamy of the treatment of a handful of such individuals drove the black waters imagery, rather than the collective experiences of the thousands of subaltern migrants who coped with the discomforts of arduous sea voyages into indenture. ${ }^{6}$ The kala pani concept thus became increasingly associated with the emotive, imaginative scenarios depicted by literary and political figures rather than with the scant gleanings of the colonial archive. It spawned patriotic novels, plays and even movies, the best known being the 1958 Hindi thriller Kala Pani, starring and produced by Dev Anand. ${ }^{7}$ It is through this patriotic recounting of the role of transportation in India's freedom struggle that the term kala pani became most commonly known by the mid-twentieth century.

\section{LAYERING KALA PANI: METAPHOR AND SYMBOLISM FROM TAGORE TO TORABULLY}

The journeys of the Bengali intellectual Rabindranath Tagore to countries on the south-eastern rim of the Indian Ocean, undertaken as a 'pilgrimage' to a forgotten Greater India in 1927, led him to revisit the notion of kala pani and offer a reassessment of the supposed Hindu religious sanctions against overseas travel. Shamsad Mortuza's analysis of the letters Tagore wrote at this time is important in its recognition of and uses for the metaphorical and symbolic power of kala pani (Mortuza 2017). For Tagore, both 'imported imperialism and home-grown nationalism were ... the metaphorical black waters - kala pani, that needed to be crossed to ... engage with the West in equal terms'. He viewed the 'literal kala pani' as a contributing factor to India's 'cultural 
withdrawal' and was an enthusiastic proponent for a scenario where the 'barriers separating cultures are broken down'. Tagore felt that Indians needed to cross a mental hurdle - 'the metaphorical kala pani, required for cultural engagement' (Mortuza 2017).

The metaphor of kala pani was employed not only by elites, but increasingly also by spokespersons for and descendants of subaltern Indians to denote the fear of the sea crossing and came to represent not just the ocean voyage into the unknown but 'the experience of dislocation' itself (Haines 2009). It signified 'a watery world outside the circuitry of the known and familiar' but this state of exile was not necessarily 'negatively received' (Moorthy and Jamal 2010: 14). On the contrary, 'forged on the "black water" (kala pani) between India and South Africa, ... was a new sense of Indian identity' (Samuelson 2010: 310).

Undoubtedly influenced by nationalist narratives, the descendants of indentured labourers, as Mathieu Claveyrolas has argued, while 'involved in strategies of victimisation through which they portray themselves as individuals brutally uprooted from their soil and culture, just like African slaves', have sought to redeploy the kala pani symbol as a mirror of the 'Middle Passage' in order to situate indenture as akin to the 'social death experienced by African slaves' (2015: 6).

On the other hand, the kala pani narrative has been reclaimed by the literary movement 'coolitude', devised by Khal Torabully, in order to stamp a distinctive and dynamic reinterpretation of indenture, avoiding essentialist connections with an idealised Mother India and anchoring migration experiences in a discourse of the global South. ${ }^{8}$ The black water crossing is thus employed to provide 'a metaphorical framework for an understanding of migrancy' (Bragard 2005: 229). Coolitude articulates a subaltern narrative, a migrant story 'which has been shipwrecked (erased) in the ocean of a Western-made historical discourse as well as a world of publication and criticism' (Stiebel 2011). In the words of Persaud (forthcoming): 'Exile grants us multiple Kala Panis: our 
bodies are vessels, verse by verse and limb by limb. Coolitude transpires as re-emergence of the shipwrecked odyssey, cane stalk genealogy. Exile affords the genesis of a third dawn: our bodies forge contours of a new Indo-history.' This positive re-envisioning of the black waters trope has in turn helped to foster a renaissance of diaspora writing centred on the reimagined crossing, at once traumatic and empowering.

\section{REDEPLOYING KALA PANI: LITERARY DEVICES AND ARTISTIC INTERPRETATIONS}

Increasingly kala pani is used as a literary and creative device, a tool for descendants of indentured migrants, and the writers and artists who excavate their encounters, to imagine and express the experiences and feelings of their ancestors. Both in academic texts and in literary narratives, kala pani is being reworked as a short-hand term to refer to the 'crossing of the Indian and Atlantic oceans by thousands of economically disenfranchised Indian agricultural workers under a pernicious system of indentured labour' (Mehta 2010). More broadly, it has become a metaphor for discussing the specificities and generalities of Indian and other marginalised labouring communities in colonial and post-colonial contexts (Rastogi 2008: 6).

Reference, for example, is made to 'kala pani voices' as a description for authors of indenture heritage, while in Indian diaspora literature, 'kala pani literary narratives' are defined as those that 'chronicle the history of indenture and the experiences of indentured Indians' (Bragard 2010; Deloughrey 2011). Latterly, a 'gendered kala pani' has emerged, refining the concept to evoke the sea passage as a further transgression - one of sex and society in the form of an escape from patriarchal restrictions. In the words of Mehta: 'transgressive boundary crossings ... enabled Indian women to escape from Hindu patriarchal structures in India that 
made them victims of abusive family and communal traditions' (2004b: 553). 'Kala pani crossings' are viewed as physical and spiritual dislocations - the journeying into feared encounters and the erasures of past attachments, a suspension of existence and an absence of belonging. At the same time, the momentous decision to leave behind the motherland is also represented as an opportunity to discard anachronistic notions of 'purity' and to embrace new identities in mosaic, hybrid societies. 'Kala pani hybridity' recognises the crossover between the African and Indian experience of sea crossings, and the shared experiences of enslaved and indentured workers (Bannerjee 2010).

The pioneering work of Khal Torabully is frequently evoked in the new kala pani literature. When Brinda Mehta speaks of 'rhizomatic spatiality' bridging the crossings of the Atlantic and Indian Ocean worlds, she is articulating concepts developed by the poetics of coolitude and adapted further by Mauritian, South African and Caribbean authors of indenture heritage (Govinden 2009; Mehta 2004a). David Dabydeen's poetry has also forged connections between the Middle Passage and the kala pani which have been widely cited (Darroch 2009: 166-9). From this elaboration of a diasporic poetics, the kala pani concept which at its origin signals a warning and a disruption has been skilfully transformed into a unifying concept: that of 'a singular subaltern plantation experience' which evades essentialist divides and draws together peoples and systems which have often historically been treated separately (Mishra 2007: 22). This spirit of inclusivity has been further enhanced by the incorporation of the jahaji-bhain (the female equivalent of the ship-brother) to create a gendered kala pani literary narrative, particularly by Caribbean authors (Pirbhai 2010).

The literary device of the kala pani crossing embodies the negative origin of the break with the past but incorporates a new, positive element - the moment of creativity, the creation of a life-changing new reality. Amitav Ghosh's Indian Ocean novel Sea of Poppies (2008) serves as a brilliant example of the 
ship voyage as a defining life-altering experience. Ghosh, Torabully and others have effectively offered a new voice to the subaltern migrant. The kala pani discourse has become more than a dramatisation of a paradigmatic journey through historical time and metaphorical space; it is a discourse on the liberation of borderlessness and a loss - of caste - that is paradoxically a gain. In this revisioning the black waters are transformed into a space of enlightenment whilst kala pani remains a potent metaphorical memorialisation. It is evoked as a symbol of remembered pain and servitude (Amharai 2013).

Patricia Mohammed (2009) has underscored why in the postcolonial, post-indenture societies, the unifying coda of kala pani imagery is so valuable. She points out that for descendants of African slavery and of Indian indenture to engage in a weighing of the historical scales is 'not justifiable, nor should it be a necessary entry requirement to nationalism or citizenship to claim that my pain is greater than yours'. While historiography continues to fight on these sterile battlegrounds, infers Mohammed, the poetical framework has proved to be a more powerful tool with which to 'attempt to move these societies beyond the literalness of any single group's narrative to the melding of the historical experience which of necessity contains both the agony and ecstasy of survival'. This is a perceptive analysis of both the rationale and the force of coolitude and kala pani poetics.

Contemporary artists of indenture heritage like Maya Mackrandilal and Andil Gosine have furthered the reclamation project and enlarged the temporal perspective of kala pani through their visual engagement with the concept in the context of "past and future time for those living in the diasporic space of North America' (Mohabir 2019). Building upon Khal Torabully's precept that the 'coolies' voyage across the seas left an indelible stamp on the imaginary landscape of coolitude', Gosine's performative piece 'Our Holy Waters and Mine' recreates the voyage and exhibits 'a series of mason jars inscribed with bodies of water that symbolise 
the shared journeys of migrant workers and his own personal life stories' (Torabully 1996; Mohabir 2014). In his art, the kala pani rupture is 'interwoven with complex shared and individualised transoceanic pasts to incite the watcher to meditate on how we can make memory meaningful to each of us' (Mohabir 2014).

The conceptual leap from kala pani as an articulation of pain and loss to one of gain by the descendants of Hindu, Indian migrants is seldom delineated as starkly as in these few lines from the pen of Indo-Mauritian Tiberman Sajiwan Ramyead, who wrote as part of an homage to the memory of a member of the white Leclezio family,

[the] struggle for freedom, social justice and the sheer economic advancement of the island was arduously undertaken by individuals from several communities... The bold acknowledgment of this fact is not laid down in many, if not most of our history books. The Indian immigrants to Mauritius and several other colonies owe their migration across the kala pani, generally a blessing for them in the medium and long term, to one factor only and none other - sugar. (Ramyead 2006)

The circuitous kala pani journey from taboo to blessing, from restriction to enlargement, from opposition to acceptance, is an instructive lesson in the dynamic nature of diasporic discourse.

Kala pani exists today largely as a creative device enabling poets, novelists and artists of the Indian labour diaspora to broach the sprawling subject of life-changing journeys. It is a powerful symbolic and metaphorical tool, and its transformations demonstrate how literature and art can be employed to build upon the excavation work of historians in archives, both to fill lacunae and to popularise narratives of subaltern agency for wider audiences. In the process, of course, novelistic techniques and artistic interpretations can at times develop dynamic offshoots and tangential courses that do not necessarily, and perhaps need not, have a firm grounding in historical realities. 


\section{ACKNOWLEDGEMENTS}

For correspondence: crispinbates@mac.com, marinadcarter@yahoo. co.uk. Research for this paper was undertaken in the National Archives of the United Kingdom, Myanmar, South Africa, Malaysia, Sri Lanka, Singapore, Fiji, Trinidad, Guyana and Mauritius as part of the 'Becoming Coolies' research project at Leeds and Edinburgh Universities, funded by the UK Arts and Humanities Research Council. Further research support was provided by Sunway University, Kuala Lumpur, Malaysia.

\section{NOTES}

1 Military rolls for the Indian troops who embarked for the expedition to the Mascarenes can be seen at India Office Records (IOR)/L/ MIL/5/167-171 Prize Rolls Bourbon \& Mauritius 1809-1810.

2 The demand for cattle carriages refers to the need to carry heavy backpacks for the food they each transported to enable them to prepare their victuals while travelling.

3 The classic expositions on the colonial imagining of Indian culture and religion are Inden 1990 and Cohn 1996. See also Singh 1996; Dirks 2001. On the influence of European ideas of race on British constructions of India see Bayly 1995; Bates 1995.

4 India Public Proceedings, Major D. G. Pitcher, Judge, Small Cause Court, Lucknow to Secy to Govt NWP and Oudh, 17 June 1882, IOLR/P/257, paras 54-67.

5 Grierson 1883, and Major D. G. Pitcher, 'Report on System of Recruiting Labourer for the Colonies', 17 June 1882, NAI, Revenue and Agriculture Department, Emigration branch, February 1883, Proceedings Nos. 1-12, appendix 6 (Notice to coolies intended to emigration to British Guiana, generally called Demarara), and Diary of Tour, entry for 16 March 1882 (interview with Ganga Din Misr of Adampur).

6 Sen 2000. The very useful two-page preface discusses the enduring myth of the 'kala pani' - the notion that natives of India dreaded sea travel, and were concerned about loss of caste in these terms.

7 Veer Savarkar's experiences in the Andamans jail were most recently retold in the epic Malayalam historical drama film Kaalapani (1996). 
8 The poetology of Coolitude was first expressed in the Frenchlanguage works of Khal Torabully, particularly Cale d'Etoiles and latterly in Anglophone writings such as Torabully 1996; Carter and Torabully 2002.

\section{REFERENCES}

Amharai, V. 2013. 'Récits postcoloniaux, retour colonial et diaspora indienne à Maurice', Loxias-Colloques, 3.

Anderson, C. 2000. Convicts in the Indian Ocean Transportation from South Asia to Mauritius, 1815-53 (London: Palgrave).

Anderson, C. 2005. 'The Bel Ombre Rebellion: Indian Convicts in Mauritius, 1815-53' in G. Campbell (ed.), Abolition and Its Aftermath in the Indian Ocean Africa and Asia (London: Routledge).

Anderson, C. 2009. 'Convicts and Coolies: Rethinking Indentured Labour in the Nineteenth Century', Slavery and Abolition, 30(1): 93-109.

Anderson, C. 2013. 'The Age of Revolution in the Indian Ocean, Bay of Bengal, and South China Sea: A Maritime Perspective', International Review of Social History, (December): 229-51.

Anderson, C. 2016. 'A Global History of Exile in Asia c1700-1900' in R. Ricci (ed.), Exile in Colonial Asia: Kings, Convicts, Commemoration (Honolulu: University of Hawaii Press).

Banerjee, A. C. (ed.). 1969. Fort William-India House Correspondence, vol. 20 (Delhi: Govt of India), pp. xxxvii-xxxviii.

Bannerjee, R. 2010. 'The Kala Pani Connection: Francophone Migration Narratives in the Caribbean Writing of Raphaël Confiant and the Mauritian Writing of Ananda Devi', Anthurium: A Caribbean Studies Journal, 7(1): 1-11.

Basham, A. L. 1964. 'Notes on Seafaring in Ancient India' in Studies in Indian History and Culture (Calcutta: Sambohi Publications), 146-66.

Bass, Daniel. 2017. Everyday Ethnicity in Sri Lanka: Up-Country Tamil Identity Politics (London: Routledge).

Bates, Crispin. 1995. 'Race, Caste and Tribe in Central India' in Peter Robb (ed.), The Concept of Race in South Asia (Oxford: Oxford University Press).

Bayly, Susan. 1995. 'Caste and "Race"' in Peter Robb (ed.), The Concept of Race in South Asia (Oxford: Oxford University Press).

Bindra, S. C. 2002. 'Notes on Religious Ban on Sea Travel in Ancient India', Indian Historical Review, 29(1-2): 34-7. 
Boodhoo, R. 2010. Health, Disease and Indian Immigrants in Nineteenth Century Mauritius (Port Louis: Apravasi Ghat Trust Fund).

Bragard, V. 2005. 'Transoceanic Echoes: Coolitude and the Work of the Mauritian Poet Khal Torabully', International Journal of Francophone Studies, 8(2): 229.

Bragard, V. 2010. 'L'Empreinte des Kala pani dans la littérature caribéenne et mauricienne: une comparaison transcoloniale', L'Esprit créateur, 50(2): 86-94.

Carroll, Lucy. 1979. 'The Seavoyage Controversy and the Kayasthas of North India, 1901-1909', Modern Asian Studies, 13: 265-99.

Carter, M. and K. Torabully. 2002. Coolitude: Anthology of the Indian Labour Diaspora (London: Anthem Press).

Claveyrolas, Mathieu. 2015. 'The "Land of the Vaish"? Caste Structure and Ideology in Mauritius', SAMAJ: South Asia Multidisciplinary Academic Journal, 6.

Cohn, Bernard. 1996. Colonialism and Its Forms of Knowledge: The British in India (Princeton, NJ: Princeton University Press).

Committee on Prison-Discipline. 1838. Report of the Committee on Prison Discipline (Calcutta: Baptist Mission Press), Appendix C: 'Minute by Mr. Macfarlan on the Question of Transportation'.

Darroch, Fiona. 2009. Memory and Myth Postcolonial Religion in Contemporary Guyanese Fiction and Poetry (Amsterdam: Rodopi).

Deloughrey, Elizabeth. 2011. 'On Kala Pani and Transoceanic Fluids', New Literature Review, 47: 71-92.

Dirks, Nicholas B. 2001. Castes of Mind: Colonialism and the Making of Modern India (Princeton, NJ: Princeton University Press).

Eales, C. 1862. Captain C. Eales, Protector of Emigrants at the Port of Calcutta, to Junior Secretary to the Government of Bengal, 29 January 1862, India Office Library and Records (IOLR) P/15/77.

Geoghegan. 1874. Geoghegan Report on Colonial Emigration, Parliamentary Papers (PP) 1874, XLVII, 0.75.

Govinden, Devarakshanam Betty. 2009. 'Healing the Wounds of History: South African Indian Writing', Current Writing: Text and Reception in Southern Africa, 21 (1-2): 286-302

Grierson, George A. 1883. 'Report on Colonial Emigration from the Bengal Presidency', Diary, IOLR V/27/820/35.

Haines, J. J. 2009. 'Intimate Spaces and Plantation Landscapes in Nineteenth-Century Mauritius: Archaeology of Indentured Laborers in the Western Indian Ocean', BA thesis, University of Chicago.

Inden, Ronald. 1990. Imagining India (Oxford: Basil Blackwell). 
Kumar, A. 2015. 'Songs of Abolition: Anti-Indentured Campaign in Early 20th Century India' in P. Kumar (ed.), Indian Diaspora Socio-Cultural and Religious Worlds (Leiden: Brill).

Mandal, Somdatta (ed. and tr.). 2014. Wanderlust: Travels of the Tagore Family (Kolkata: Visva-Bharati).

Mehta, Brinda J. 2004a. Diasporic (Dis)locations: Indo-Caribbean Women Writers Negotiate the Kala Pani (Kingston, Jamaica: University of the West Indies Press).

Mehta, Brinda J. 2004b. 'Kali, Gangamai, and Dougla Consciousness in Moses Nagamootoo's Hendree's Cure', Callaloo, 27/2: 553

Mehta, Brinda J. 2010. 'Indianités francophones: Kala Pani Narratives', L'Esprit Créateur, 50(2): 1-11.

Meredith, David. 1988. 'Full Circle: Contemporary Views on Transportation', in S. Nicholas (ed.), Convict Workers: Reinterpreting Australia's Past (Cambridge: Cambridge University Press).

Mishra, Vijay. 2007. The Literature of the Indian Diaspora: Theorizing the Diasporic Imaginary (New York: Routledge).

Mohabir, N. 2014. 'Our Holy Waters and Mine: The Art of Andil Gosine', The Immigrant Issue (Spring).

Mohabir, N. 2019. 'Kala Pani: Aesthetic Deathscapes and the Flow of Water After Indenture', Asian Diasporic Visual Cultures and the Americas, 5(3): 293-314.

Mohammed, Patricia. 2009. 'Morality and the Imagination - Mythopoetics of Gender and Culture in the Caribbean', South Asian Diaspora, 1(1): 63-84.

Moorthy, S., and A. Jamal (eds). 2010. Indian Ocean Studies Cultural, Social, and Political Perspectives (London: Routledge).

Mortuza, S. 2017. 'Beyond "Kalapani” and Tagore's Search for a Shared Regional Identity', Journal of the Indian Ocean Region, 13(3): 284.

Mouat, F. J. [1857] 'Report on the Mortality of Emigrant Coolies on the Voyage to the West Indies, in 1856-7', India Office Records (IOR) P.188.57 (India Public), pp. xviii-xix.

Pearson, Michael. 2007. The Indian Ocean (London: Routledge).

Persaud, S. Forthcoming. From Calcutta to Kingston: A Cartography of Coolitude.

Pirbhai, Mariam. 2010. 'The Jahaji-Bhain Principle: A Critical Survey of the Indo-Caribbean Women's Novel, 1990-2009', Journal of Commonwealth Literature, 45(1): 37-56.

Ramyead, Tiberman Sajiwan. 2006. 'Apropos Fernand Leclézio, Savanne Mon Amour and the MGI', Mauritius Times (13 October).

Rastogi, P. 2008. Afrindian Fictions: Diaspora, Race, and National Desire in South Africa (Columbus, OH: Ohio State University Press). 
Raychaudhuri, T. 1988. Europe Reconsidered: Perceptions of the West in Nineteenth Century Bengal (Oxford: Oxford University Press).

Samaroo, B. 2004. "The 1862 "Mutiny" aboard the Guyana-Bound Clasmerden', The Arts Journal, 1(1): 84.

Samuelson, Meg. 2010. 'A Traveling Science: Anthropometry and Colonialism in the Indian Ocean' in S. Moorthy and A. Jamal, Indian Ocean Studies Cultural, Social, and Political Perspectives (London: Routledge).

Sen, A. 1961. 'The Structure and Organisation of the Bengal Native Infantry with Special Reference to Problems of Discipline, 1796-1852', D.Phil. SOAS, University of London.

Sen, Satadru. 2000. Disciplining Punishment: Colonialism and Convict Society in the Andaman Islands (Oxford: Oxford University Press).

Singaravelou. 1975. Les Indiens de la Guadeloupe: Etude de Geographie Humaine (Guyana: Centre Universitaire Antilles-Guyane).

Singh, Jyotsna G. 1996. Colonial Narratives/Cultural Dialogues: 'Discoveries' of India in the Language of Colonialism (London: Routledge).

Stiebel, Lindy. 2011. 'Crossing the Kala Pani: Cause for "Celebration" or "Commemoration" 150 Years on? Portrayals of Indenture in Recent South African Writing', Journal of Literary Studies, 27: 84.

Tinker, H. 1974. A New System of Slavery: The Export of Indian Labour Overseas 1830-1920 (London: Oxford University Press).

Torabully, Khal. 1996. 'The Coolies' Odyssey', The UNESCO Courier (Paris, October).

Yang, A. A. 'Indian Convict Workers in Southeast Asia in the Late Eighteenth and Early Nineteenth Centuries', Journal of World History, 14(2): 179-208.

Yang, Anand. 2021. Empire of Convicts: Indian Penal Labour in Colonial Southeast Asia (Berkeley, CA: University of California Press). 